\title{
Researchers rue hasty destruction of wheat
}

Carina Dennis, Sydney

Hindsight is always 20/20, as researchers at one of Australia's top plant-research labs have just discovered. Last month, the laboratory destroyed most of its wheat samples - more than 40,000 plants in all because of fears that they were housing wheat streak mosaic virus, a disease that farmers desperately want to keep out of Australia.

But now it looks as if the virus is already established in Australia anyway, leaving laboratory managers worried that they might have wiped out up to a year's worth of work for nothing.

The Commonwealth Scientific and Industrial Research Organisation (CSIRO), Australia's largest research agency, first identified the virus - which can badly affect crop productivity - at two of its breeding stations in Canberra. The stations are part of CSIRO Plant Industry, an agricultural laboratory run by the agency.

"We originally thought the virus was just at our Canberra sites and we thought we could eradicate it. We didn't know that it was already in the country," says T. J. Higgins, assistant director of the lab. "Faced with the same decision, I would do it again."

The virus has since been found at several more research facilities. But these samples have been quarantined, instead of being destroyed, as part of a government-instigated assessment of the spread of the virus in Australia's research facilities and wheatfields.

"I feel confident that the virus has been here for a long time - at least since the 1990s," says Anthony Rathjen, a wheat breeder at the University of Adelaide's Waite campus, the second site at which the virus was detected.

But the conclusion that the virus is already found in Australia comes a bit late for the CSIRO plant laboratories. "We're currently estimating the costs and it could take a year or so for some breeding programmes to recover," says Higgins. "Morale was initially very low, but people are now bouncing back."

Wheat producers are not very happy either. "We depend on new varieties, and the destruction at the CSIRO has meant that a lot of the valuable material has been lost," says Murray Jones, senior vice-president of the Canberra-based Grains Council of Australia. Nonetheless, he adds, "at the time, the right decision was made".

Farmers remain hopeful that, in Australia, the virus is confined to plant-breeding laboratories, where the vector mite that transmits it enjoys a constant supply of young, green wheat. "I think it's a great nuisance for glasshouses but is insignificant as far the industry is concerned," says Rathjen.

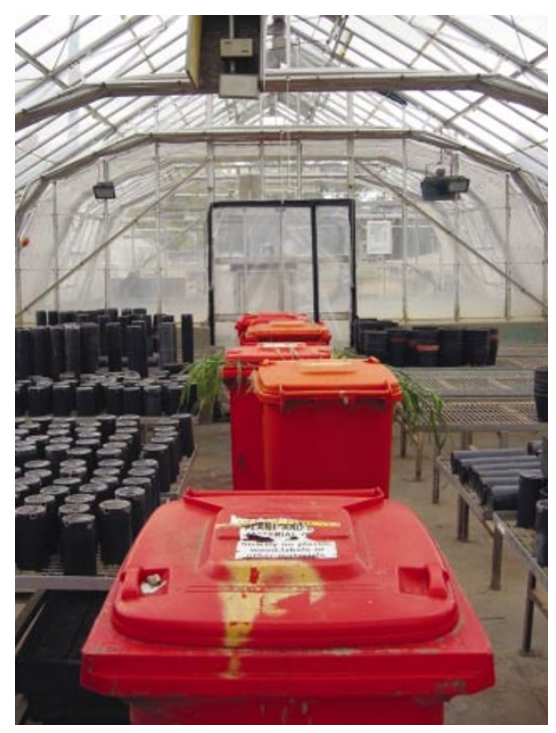

Binned: researchers killed 40,000 wheat plants in a bid to quell wheat streak mosaic virus.

The virus is already endemic in the wheatfields of the United States, where it results in a small but significant loss of productivity. But Australian wheat farmers want it kept out. "Every continent is different and you can't extrapolate," says Higgins. "The disease might be much worse or much less damaging for Australia."

\section{Cash crisis casts pall over synchrotron X-ray source}

\section{Carina Dennis, Sydney}

Plans to build a synchrotron X-ray source in Melbourne could be heading for trouble, researchers say, after federal and state government officials clashed over who should foot the bill.

The state government of Victoria has pledged the A $\$ 157$ million (US\$102 million) needed to build the facility, the construction

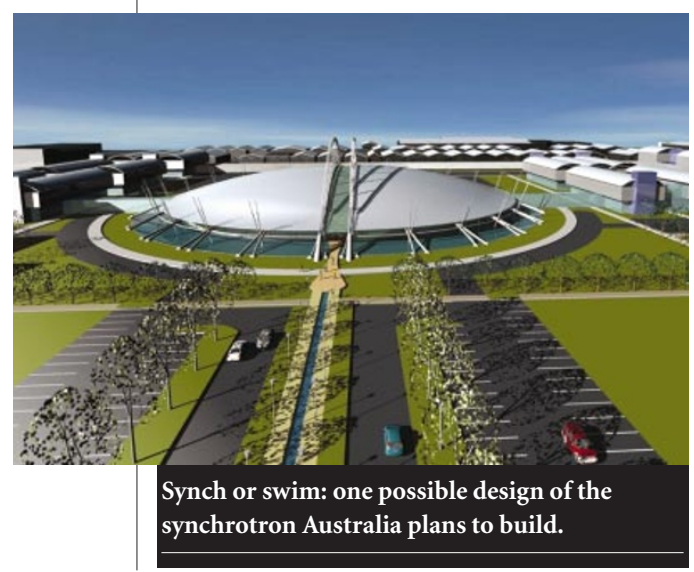

of which should begin later this year. But project planners need another $\mathbf{A} \$ \mathbf{5 0}$ million to build the 'beamlines', which will channel the $\mathrm{X}$-rays produced as particles shoot around the synchrotron's central ring.

Victoria had hoped that the federal government would help to pay for the beamlines. "We have punched well beyond our weight, and now its time for the federal government to come on board," says John Brumby, Victoria's innovation minister.

But on 11 May, the federal science minister, Peter McGauran, said that the government would not allocate money specifically for the synchrotron. It will instead have to compete for funds from existing programmes, such as those of the Australian Research Council and the National Health and Medical Research Council. This means that any federal money for the project looks likely to come at the expense of scientists' grants.

The facility's prospective users fear that squabbling between the conservative, federal government and the Labour-led state government in Melbourne will damage
Australia's largest-ever scientific project.

"It is unthinkable that the federal government would not make some contribution to a facility of such great national benefit," says Peter Darvall, vicechancellor of Monash University, where the synchrotron is to be built.

Researchers, who hope to use the synchrotron's X-rays to probe threedimensional molecular structures, are exploring many avenues to find the money. "We envisaged that the scientific community would be principally responsible" for raising it, says Frank Larkins, chair of an advisory committee coordinating the construction of the beamlines and an administrator at the University of Melbourne, which has agreed to fund at least one beamline itself.

Larkins is still hopeful that the money can be found. "Once we have prepared the scientific case, we will be approaching a range of bodies, including the federal government, research agencies, universities and industry," he says. "If we don't have the commitment of funds in 18 months, then we will start to be concerned." 